Article

\title{
Acute Toxic and Genotoxic Effects of Aluminum and Manganese Using In Vitro Models
}

\author{
Luiza Flavia Veiga Francisco ${ }^{1}$, Debora da Silva Baldivia ${ }^{2}$, Bruno do Amaral Crispim ${ }^{2}(\mathbb{D}$, \\ Syla Maria Farias Ferraz Klafke ${ }^{2}$, Pamella Fukuda de Castilho ${ }^{3} \mathbb{}{ }^{-1}$, Lucilene Finoto Viana ${ }^{2}$, \\ Edson Lucas dos Santos ${ }^{2}$, Kelly Mari Pires de Oliveira ${ }^{2}\left(\mathbb{D}\right.$ and Alexeia Barufatti ${ }^{2, *}$ \\ 1 Faculty of Exact Sciences and Technology, Federal University of Grande Dourados, \\ Dourados 79.804-970, Mato Grosso do Sul, Brazil; luizaveiga10@hotmail.com \\ 2 Faculty of Biological and Environmental Sciences, Federal University of Grande Dourados, \\ Dourados 79.804-970, Mato Grosso do Sul, Brazil; deborabaldivia@outlook.com.br (D.d.S.B.); \\ brunocrispim.bio@gmail.com (B.d.A.C.); sylamklafke@gmail.com (S.M.F.F.K.); \\ lucilenefinoto@hotmail.com (L.F.V.); edsonsantos@ufgd.edu.br (E.L.d.S.); \\ kellyoliveira@ufgd.edu.br (K.M.P.d.O.) \\ 3 Postgraduate Program in Health Science, Federal University of Grande Dourados, \\ Dourados 79.804-970, Mato Grosso do Sul, Brazil; pamellafcastilho@gmail.com \\ * Correspondence: barufattialexeia@gmail.com; Tel.: +55-67-3410-2255
}

\section{check for} updates

Citation: Francisco, L.F.V.; Baldivia, D.d.S.; Crispim, B.d.A.; Klafke, S.M.F.F.; Castilho, P.F.d.; Viana, L.F.; Santos, E.L.d.; Oliveira, K.M.P.d.; Barufatti, A. Acute Toxic and Genotoxic Effects of Aluminum and Manganese Using In Vitro Models. Toxics 2021, 9, 153. https://doi.org/ $10.3390 /$ toxics 9070153

Academic Editors: Michael Aschner and Joshua R. Edwards

Received: 27 March 2021

Accepted: 3 May 2021

Published: 30 June 2021

Publisher's Note: MDPI stays neutral with regard to jurisdictional claims in published maps and institutional affiliations.

Copyright: (c) 2021 by the authors. Licensee MDPI, Basel, Switzerland. This article is an open access article distributed under the terms and conditions of the Creative Commons Attribution (CC BY) license (https:/ / creativecommons.org/licenses/by/ $4.0 /)$.

\begin{abstract}
The objective of this study was to use the same concentrations of aluminum (Al) and manganese $(\mathrm{Mn})$ detected previously in groundwater above those permitted by Brazilian law and assess their cytotoxic and genotoxic effects in hamster ovary cell lines and their mutagenic effects through the Salmonella microsome assay. Chinese hamster ovary $(\mathrm{CHO})$ and $\mathrm{CHO}-\mathrm{XRS} 5$ cells were treated with different concentrations of $\mathrm{Al}$ and $\mathrm{Mn}(0.2$ to $2.0 \mathrm{mg} / \mathrm{L}$ and 0.1 to $3.0 \mathrm{mg} / \mathrm{L}$, respectively). The Ames test was used to analyze the concentrations of $\mathrm{Al}$ and $\mathrm{Mn}$ ranging from 0.025 to $1.0 \mathrm{mg} / \mathrm{L}$ and 0.0125 to $1.5 \mathrm{mg} / \mathrm{L}$, respectively. Both metals showed cytotoxic effects on both cell lines and two bacterial strains (TA98 and TA100). The genotoxic effects of the highest concentrations of Al and $\mathrm{Mn}$ in cell lines showed nuclear buds, micronuclei, and DNA damage; however, none of the concentrations showed a positive mutagenic response in the Ames test. This is one of the few studies to demonstrate the cytotoxic effects of $\mathrm{Al}$ and $\mathrm{Mn}$ through the Ames test. In addition, the metals caused genomic instability in cell lines. Therefore, this study may help hasten the review of established regulatory standards for human consumption of groundwater.
\end{abstract}

Keywords: metals; cytotoxicity; micronucleus; comet assay; Ames test; $\mathrm{CHO}$ cells

\section{Introduction}

Exposure to metals in the environment at concentrations above of the values considered safe by legislation can adversely affect organisms [1-3]. Metal contamination in the environment occurs from both natural sources, such as rocks and volcanoes, and anthropogenic sources, such as through industrial processes, mining, pesticides, medication, and water treatment [4,5]. Contaminated food and drinking water are the most common sources of human exposure to metals [6,7]. Food contamination is mainly caused by the use of pesticides containing metals in agriculture, whereas contamination of water is mainly caused by inadequate disposal of these metals in the soil due to agricultural, industrial, and landfill activities, which can contaminate surface and groundwater through percolation and leaching processes [8].

Aluminum (Al) is the most abundant metal on the Earth's surface. It is used on a large scale for food packaging and in kitchen utensils [9], which can act as sources of Al toxicity to humans as $\mathrm{Al}$ does not have a biological role in living organisms [10]. Manganese (Mn) is the fifth most abundant metal and is considered an essential element for humans because 
it plays an important role in several physiological processes, such as the regulation of reproduction and bone growth and the maintenance of brain function [11,12]. However, in concentrations above the limit permitted by law (CONAMA), Mn can cause negative effects on human health.

Excessive amounts of $\mathrm{Al}$ and $\mathrm{Mn}$ pose long-term risks for human health. $\mathrm{Al}$ and $\mathrm{Mn}$ induce changes in the morphology of organs as well as cause cytotoxicity and genotoxicity [13-17]. Moreover, these metals may accumulate in the central nervous system and increase the risk of developing diseases, such as Alzheimer's disease, Parkinson's disease, and manganism syndrome [12,18-20].

Since the Chinese hamster ovary $(\mathrm{CHO})$ cell line is representative or predictive of the human micronucleus (MCN) response, in the present study, $\mathrm{CHO}$ and $\mathrm{CHO}-\mathrm{XRS5}$ were used to test the hypothesis that $\mathrm{Al}$ and $\mathrm{Mn}$ induce cytotoxicity, genotoxicity, and mutagenicity. $\mathrm{CHO}$ cells, derived from the normal ovarian epithelial cells of Chinese hamsters, are well-characterized and have a short generation time (12-14 h) and a small number of chromosomes $(2 n=20-22)$ compared to the human karyotype $(2 n=46)$ [21]. CHO cells are highly recommended as a model for the in vitro assessment of toxicity and genotoxic potential as the results obtained with it mimic those of human cells [22]. Furthermore, the Organization for Economic Cooperation and Development (OECD) guidelines [23] favor the use of cell lines from Chinese hamsters. CHO-XRS cells are deficient in their ability to repair double-stranded DNA and are more efficient in the repair of single-strand breaks $[24,25]$. This inability prevents proper recombination and leads to changes in the DNA, which makes it a valuable tool for the evaluation of the mechanisms related to DNA break repair and chromosomal abnormalities caused by the toxic action of $\mathrm{Al}$ and Mn $[26,27]$.

In our previous study, we assessed the quality of groundwater in two cities in Mato Grosso do Sul, Brazil [28] since its population is supplied entirely by groundwater, which is normally consumed without prior treatment. We identified $\mathrm{Al}$ and $\mathrm{Mn}$ concentrations above the maximum limits allowed $(0.2$ and $0.1 \mathrm{mg} / \mathrm{L}$, respectively) by regulation $396 / 2008$ of the National Council for the Environment [29], which specifies the maximum limits allowed for metals in groundwater intended for human consumption. To identify the potential effects caused by $\mathrm{Al}$ and $\mathrm{Mn}$ in the populations of these cities, the objective of this study was to use the same concentrations of $\mathrm{Al}$ and $\mathrm{Mn}$ detected previously and assess their cytotoxic and genotoxic effects in hamster ovary cell lines and their mutagenic effects through the Salmonella microsome assay.

\section{Materials and Methods}

\subsection{Cell Culture}

\subsubsection{Cell Lines and Treatments}

Hamster ovary cell lines CHO and CHO-XRS5 were cultured in HAM-F10 (SigmaAldrich, St. Louis, MO, USA) and Dulbecco's Modified Eagle's Medium (DMEM) powder (high glucose) (Gibco, Carlsbad, CA, USA) supplemented with 10\% fetal bovine serum (FBS) (Gibco, Carlsbad, CA, USA), $5 \mathrm{mg}$ of penicillin, $5 \mathrm{mg}$ of streptomycin, $10 \mathrm{mg}$ of neomycin (Gibco, Carlsbad, CA, USA), and $3.7 \mathrm{~g} / \mathrm{L}$ sodium bicarbonate. The cells were incubated at $37^{\circ} \mathrm{C}$ under $5 \% \mathrm{CO}_{2}$.

The concentrations of $\mathrm{Al}(0.2,0.4,0.6,0.8,1.0$, and $2.0 \mathrm{mg} / \mathrm{L})$ and $\mathrm{Mn}(0.1,0.15$, $0.3,1.0,1.5$, and $3.0 \mathrm{mg} / \mathrm{L}$ ) used in this study were based on the results of our previous study [28], in which we verified levels of $\mathrm{Al}$ and $\mathrm{Mn}$ within this concentration range in groundwater intended for human consumption. Stock solutions $(1000 \mathrm{mg} / \mathrm{L})$ of $\mathrm{Al}$ and $\mathrm{Mn}$ (SpecSolô, SEM-682, Jacareí, Brazil) were used. Mitomycin C (2 $\mu \mathrm{g} / \mathrm{L})$ (Sigma-Aldrich, St. Louis, MO, USA) was used as a positive control (PC) to the cytokinesis-block micronucleus cytome (CBMN Cyt) and comet assay, and culture medium alone was used as the negative control (NC). 


\subsubsection{Cytotoxicity Assay}

Cell viability was assessed through a colorimetric assay using 3-(4,5-dimethylthiazol2-yl)-2,5-diphenyltetrazolium bromide (MTT, Sigma-Aldrich, St. Louis, MO, USA). For each concentration of the metals evaluated, three independent experiments were carried out in triplicates. For this, $\mathrm{CHO}$ and CHO-XRS5 cells $\left(6 \times 10^{3}\right.$ cells $\left./ \mathrm{mL}\right)$ were treated with $\mathrm{Al}$ and $\mathrm{Mn}$ for 24 and $72 \mathrm{~h}$ at $37{ }^{\circ} \mathrm{C}$ with $5 \% \mathrm{CO}_{2}$. To ensure the same cell density until the end of the experiment, these metals were diluted in HAM-F10 + DMEM without FBS. After the treatment periods, MTT $(0.5 \mathrm{mg} / \mathrm{mL})$ was added to each well. The resulting supernatant was discarded, and dimethyl sulfoxide (DMSO, VETEC, Rio de Janeiro, Brazil) was added to solubilize the formazan crystals formed. Cell viability was calculated using the following formula:

$$
\text { Cell viability }(\%)=\left(\mathrm{Abs}_{\text {treated }} \text { cells } / \mathrm{Abs}_{\text {control }}\right) \times 100
$$

\subsubsection{CBMN Cyt Assay}

The MCN test with cytokinesis-block was performed according to the method described by Oliveira et al. [30] with some modifications. CHO and CHO-XRS5 cells $\left(4 \times 10^{5}\right.$ cells $\left./ \mathrm{mL}\right)$ were treated with $\mathrm{Al}(0.2-2.0 \mathrm{mg} / \mathrm{L})$ and $\mathrm{Mn}(0.1-3.0 \mathrm{mg} / \mathrm{L})$ in HAM$\mathrm{F} 10+$ DMEM supplemented with FBS for 24 and $72 \mathrm{~h}$ at $37^{\circ} \mathrm{C}$ with $5 \% \mathrm{CO}_{2}$. After the treatments, the cells were incubated with Cytochalasin B $(6 \mu \mathrm{g} / \mathrm{mL}$; (Sigma-Aldrich, St. Louis, MO, USA) for $20 \mathrm{~h}$. Subsequently, the cells were treated with $1 \%$ sodium citrate, fixed in a methanol:acetic acid (3:1) solution, and then stained with 5\% Giemsa (VETEC, Rio de Janeiro, Brazil). One thousand binucleated cells were analyzed for each condition. Two independent experiments with one biological replicate for each sample were performed, and two technical replicates (in slides) were analyzed for each biological replicate. Thus, 4000 binucleated cells (2000 cells from each replicate) in each tested concentration were scored to determine the number of MCNs, nucleoplasmic bridges, and nuclear buds, as described by Fenech [31].

\subsubsection{Alkaline Single-Cell Gel Electrophoresis Assay (Comet Assay)}

The comet assay was performed according to the methods of Singh et al. [32], with some modifications. $\mathrm{CHO}$ and CHO-XRS5 cells $\left(1 \times 10^{5} / \mathrm{mL}\right)$ were treated with $\mathrm{Al}$ $(0.2-2.0 \mathrm{mg} / \mathrm{L})$ and $\mathrm{Mn}(0.1-3.0 \mathrm{mg} / \mathrm{L})$ in HAM-F10 + DMEM supplemented with FBS for 24 and $72 \mathrm{~h}$ at $37{ }^{\circ} \mathrm{C}$ with $5 \% \mathrm{CO}_{2}$. An aliquot $(100 \mu \mathrm{L})$ of the cell suspension was added to low melting point agarose $(0.5 \%)$ (Thermo Fisher Scientific, Vilnius, Lithuania) at $37^{\circ} \mathrm{C}$ and placed on gelatin-coated slides with $1.5 \%$ agarose (Kasvi, São José dos Pinhais, Brazil). Afterward, the slides were immersed in a lysis solution $(2.5 \mathrm{M} \mathrm{NaCl}, 100 \mathrm{mM}$ $\mathrm{Na}_{2}$ EDTA, and $10 \mathrm{mM}$ Tris with $10 \%$ DMSO and $1 \%$ Triton X-100) at $4{ }^{\circ} \mathrm{C}$ for $90 \mathrm{~min}$. Next, the slides were transferred to a horizontal electrophoresis unit dipped in alkaline electrophoresis buffer $(0.3 \mathrm{~mol} / \mathrm{L} \mathrm{NaOH}$ and $0.001 \mathrm{~mol} / \mathrm{L}$ EDTA, $\mathrm{pH}>13)$ for $20 \mathrm{~min}$ and were electrophoresed $(37 \mathrm{~V} / \mathrm{cm}, 300 \mathrm{~mA})$ for $25 \mathrm{~min}$. Subsequently, the slides were neutralized with $0.4 \mathrm{M}$ Tris for $15 \mathrm{~min}$, fixed in ethanol, and stained with ethidium bromide $(0.02 \mathrm{~mol} / \mathrm{L})$.

The nucleoids were analyzed using the Lucia Comet Assay Single Stain software (Laboratory Imaging, Prague, Czech Republic). In each of the two independent experiments, 100 comets were measured (50 comets/slide from two replicate slides). Thus, 200 comets in each tested concentration were scored. The genotoxicity parameters used to quantify DNA damage were DNA percentage in Tail and Tail Length.

\subsection{Ames Test}

The mutagenic potential of $\mathrm{Al}(0.025,0.05,0.1,0.2,0.4,0.6,0.8$, and $1.0 \mathrm{mg} /$ plate $)$ and Mn $(0.0125,0.025,0.05,0.1,0.3,1.0$, and $1.5 \mathrm{mg} /$ plate) samples was assessed using the pre-incubation method according to the methods of Mortelmans and Zeiger [33] and the OECD guideline 471 [34]. The assay was conducted in both the presence and absence of 
exogenous metabolism using the liver of Sprague Dawley rats. The experiment was carried out in triplicates using the Salmonella enterica serovar Typhimurium strains TA98 and TA100, standardized to obtain a cell suspension of $10^{8}$ cells $/ \mathrm{mL}$. In the tests without metabolic activation, the following PCs (Positive Controls) were used: 4-nitro-phenylenediamine $(10 \mu \mathrm{g} /$ plate $)$ for the TA98 strain and sodium azide ( $2.5 \mu \mathrm{g} /$ plate) for the TA100 strain. In the tests with metabolic activation, 2-aminoanthracene $(0.625 \mu \mathrm{g} /$ plate $)$ was used for both strains. For the Negative Control, DMSO 5\% ( $5 \mu \mathrm{L} /$ plate) was used.

\subsection{Statistical Analysis}

For the cell culture tests, statistical analyses were performed using the RStudio platform [35]. The normality of all data was tested using the Shapiro-Wilk test. The results of the MTT and MCN tests were evaluated using the one-way analysis of variance parametric test and Tukey's test. The Kruskal-Wallis non-parametric test and Dunn's test were used for analyzing the comet assay results. The differences between the treatments and the NC were considered significant at $p<0.05$ for all tests.

For the Ames test, the results were analyzed by using the Salanal statistical program (U.S. Environmental Protection Agency, Monitoring Systems Laboratory, Las Vegas, NV, USA, version 1.0, from the Research Triangle Institute, Raleigh, Durham e Chapel Hill, NC, USA) and adopting the model of Bernstein et al. [36]. The mutagenicity ratio (MR) was calculated according to the following formula:

$$
\mathrm{MR}=\frac{\text { Number of induced revertants }}{\text { Number of spontaneous revertants }}
$$

Considering that the tests were performed in a single dose, the results were presented as qualitative data. The metals were considered potentially mutagenic when the MR was $\geq 2.0$, negative when the MR was $<2.0$, and toxic when the MR was $<0.7$.

\section{Results}

\subsection{Cytotoxicity}

The viability of $\mathrm{CHO}$ and $\mathrm{CHO}-\mathrm{XRS} 5$ cells was reduced upon exposure to $\mathrm{Al}$ and $\mathrm{Mn}$ for 24 and $72 \mathrm{~h}$, indicating their cytotoxic effects (Figure 1A,B).

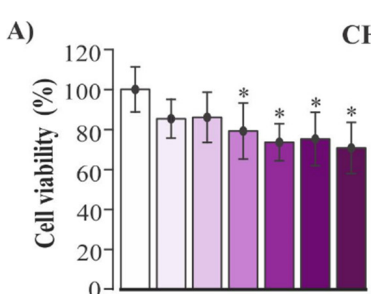

$24 \mathrm{~h}$

CHO

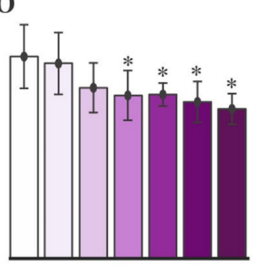

$72 \mathrm{~h}$

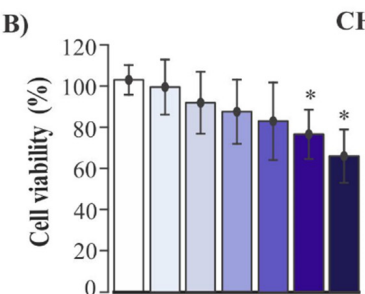

$24 \mathrm{~h}$

CHO

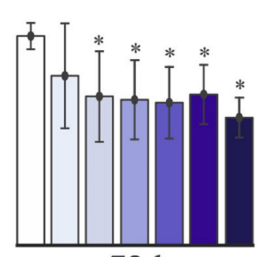

$72 \mathrm{~h}$

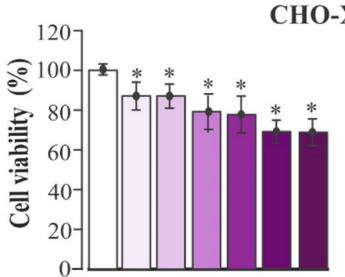

$24 \mathrm{~h}$

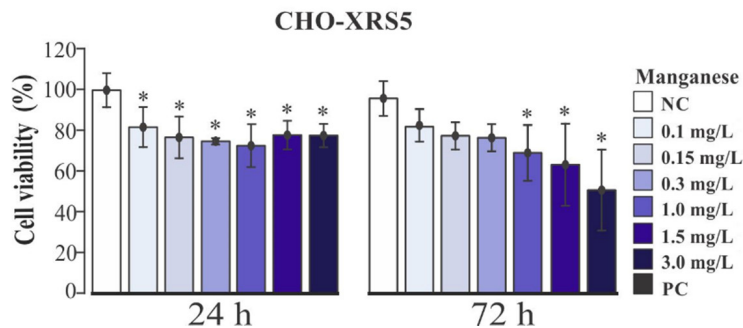

Figure 1. Viability (\%) of Chinese hamster ovary (CHO) and CHO-XRS5 cells. Cells were treated with different concentrations of aluminum (A) and manganese (B) for 24 and $72 \mathrm{~h}$. Data are expressed as means \pm standard deviation of three independent experiments performed in triplicates. ${ }^{*} p<0.05$ compared to the negative control by the analysis of variance test followed by Tukey's test. NC, negative control. 
The viability of $\mathrm{CHO}$ cells reduced significantly with $\mathrm{Al}$ concentrations $\geq 0.6 \mathrm{mg} / \mathrm{L}$ when compared to the NC during the 24 and $72 \mathrm{~h}$ periods of assessment (Figure 1A). The viability of CHO-XRS5 cells reduced with $\mathrm{Al}$ concentrations $\geq 0.2 \mathrm{mg} / \mathrm{L}$ and $\geq 0.6 \mathrm{mg} / \mathrm{L}$ for the 24 and $72 \mathrm{~h}$ time periods, respectively (Figure $1 \mathrm{~A}$ ).

The viability of $\mathrm{CHO}$ cells was reduced significantly at Mn concentrations $>1.5 \mathrm{mg} / \mathrm{L}$ when compared to the NC for the $24 \mathrm{~h}$ treatment; however, the viability of these cells was affected from a concentration of $0.15 \mathrm{mg} / \mathrm{L}$ for the $72 \mathrm{~h}$ treatment, i.e., greater toxicity was detected upon exposure for a longer duration (Figure 1B). The viability observed in CHO-XRS5 cells upon treatment with $\mathrm{Mn}$ was reduced at the lowest concentration $(0.1 \mathrm{mg} / \mathrm{L})$ after $24 \mathrm{~h}$ of treatment (Figure 1B). All concentrations of $\mathrm{Al}$ and $\mathrm{Mn}$ used for the cell viability test were used for analysis of the genotoxic effects of $\mathrm{Al}$ and $\mathrm{Mn}$ because none of them reduced the cell viability by more than $50 \%$.

\subsection{MCN Test}

In $\mathrm{CHO}$ cells, the number of nuclear buds increased significantly at $\mathrm{Al}$ concentrations above $1.0 \mathrm{mg} / \mathrm{L}$ after $24 \mathrm{~h}$ of treatment compared to that of the NC. After $72 \mathrm{~h}$ of treatment, the lowest $\mathrm{Al}$ concentration $(0.2 \mathrm{mg} / \mathrm{L})$ tested was able to induce nuclear bud formation in these cells (Figure 2A).

A)

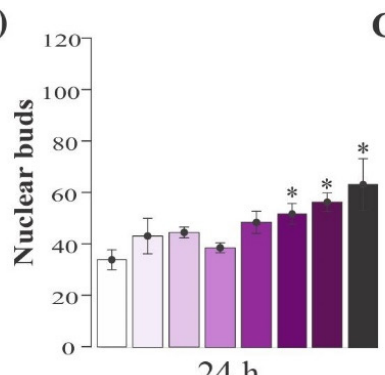

B)

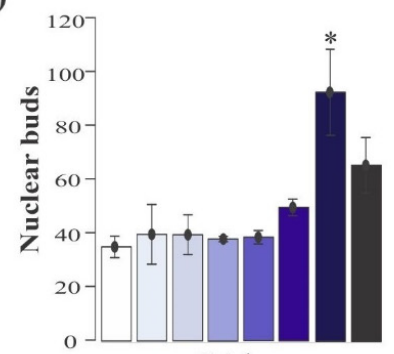

$24 \mathrm{~h}$
CHO

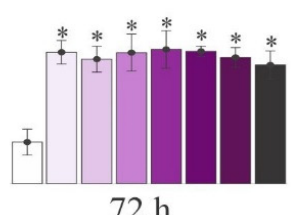

$72 \mathrm{~h}$

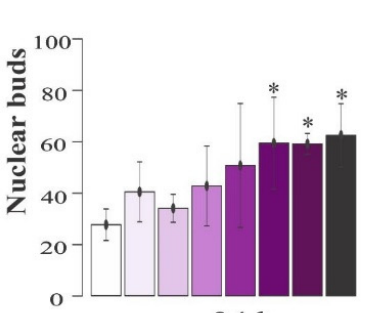

$24 \mathrm{~h}$
CHO-XRS5

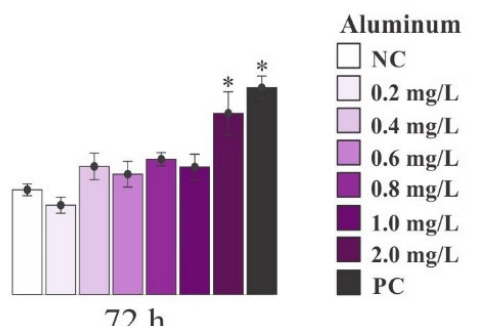

CHO-XRS5

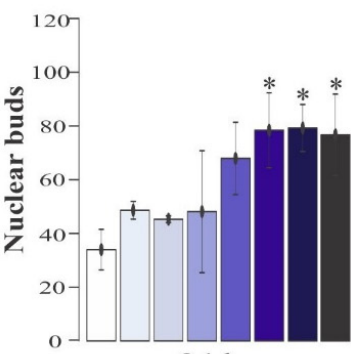

$24 \mathrm{~h}$

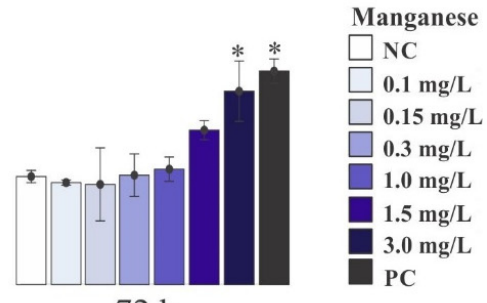

$72 \mathrm{~h}$

Figure 2. Effect of aluminum (A) and manganese (B) on nuclear bud formation in binucleated Chinese hamster ovary $(\mathrm{CHO})$ and $\mathrm{CHO}-X \mathrm{RS} 5$ cells after 24 and $72 \mathrm{~h}$ of incubation. Data are expressed as means \pm standard deviation of two independent experiments. ${ }^{*} p<0.05$ compared to the negative control via analysis of variance followed by Tukey's test. NC, negative control; PC, positive control.

In CHO-XRS5 cells, the number of nuclear buds increased significantly at $\mathrm{Al}$ concentrations above $1.0 \mathrm{mg} / \mathrm{L}$ after $24 \mathrm{~h}$ of treatment compared to that in the NC and in the highest $\mathrm{Al}$ concentration $(2.0 \mathrm{mg} / \mathrm{L})$ after $72 \mathrm{~h}$ of treatment (Figure $2 \mathrm{~A})$. In CHO cells, the number of nuclear buds was significantly different in the cells treated with 3.0 and $1.5 \mathrm{mg} / \mathrm{L} \mathrm{Mn}$ for 24 and $72 \mathrm{~h}$, respectively, compared to that in the NC (Figure 2B), whereas in CHO-XRS5 cells, this difference was observed from 1.5 and $3.0 \mathrm{mg} / \mathrm{L}$ after 24 and $72 \mathrm{~h}$, respectively (Figure 2B). Al and $\mathrm{Mn}$ did not cause any significant increase in the number of nucleoplasmic bridges in either cell type. 
In the present study, there was an increase in the $\mathrm{MCN}$ in $\mathrm{CHO}$ cells treated with $\mathrm{Al}$ compared to that in the NC during the two treatment periods. The increase in the $\mathrm{MCN}$ was significantly different compared to that in the NC in the $2.0 \mathrm{mg} / \mathrm{L}$ sample during the $24 \mathrm{~h}$ treatment period and in the 1.0 and $2.0 \mathrm{mg} / \mathrm{mL}$ samples in the $72 \mathrm{~h}$ treatment period (Figure 3A).

A)

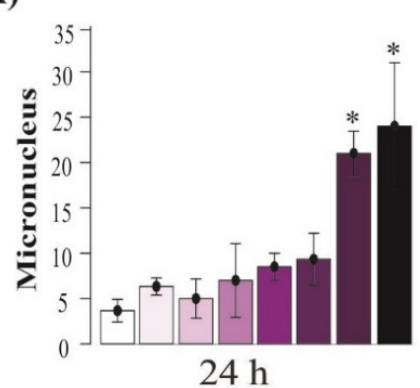

B)

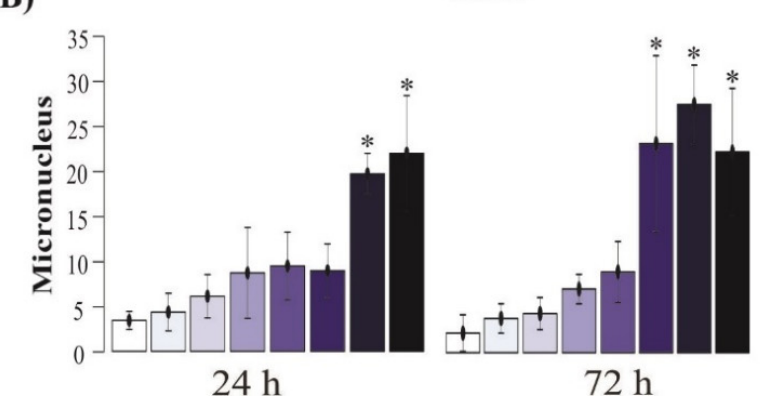

CHO

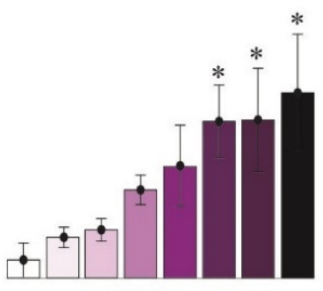

$72 \mathrm{~h}$

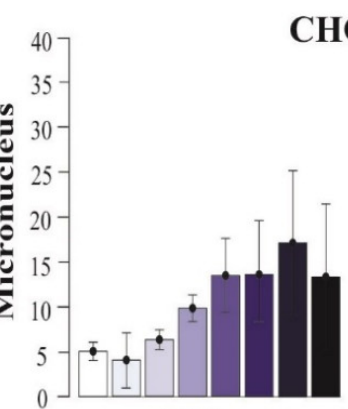

$24 \mathrm{~h}$
CHO-XRS5

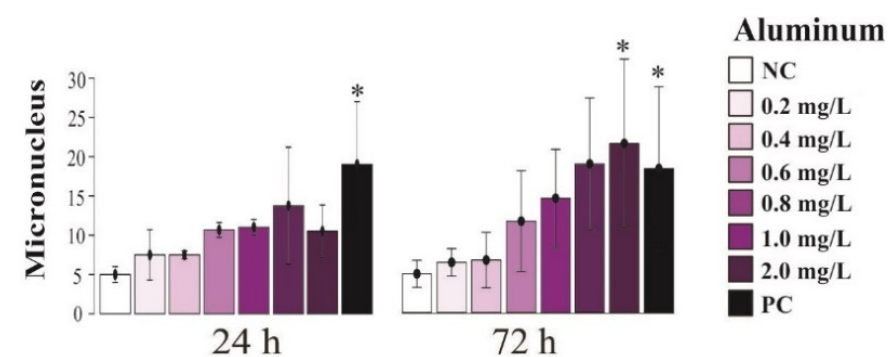

$72 \mathrm{~h}$

Manganese

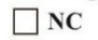

$0.1 \mathrm{mg} / \mathrm{L}$

$\square 0.15 \mathrm{mg} / \mathrm{L}$

$0.3 \mathrm{mg} / \mathrm{L}$

$1.0 \mathrm{mg} / \mathrm{L}$

$1.5 \mathrm{mg} / \mathrm{L}$

$3.0 \mathrm{mg} / \mathrm{L}$

$72 \mathrm{~h}$

Figure 3. Effect of aluminum (A) and manganese (B) on micronucleus formation in binucleated Chinese hamster ovary $(\mathrm{CHO})$ and $\mathrm{CHO}-\mathrm{XRS} 5$ cells after 24 and $72 \mathrm{~h}$ of incubation. Data are expressed as means \pm standard deviation of two independent experiments. ${ }^{*} p<0.05$ compared to the negative control via analysis of variance followed by Tukey's test. NC, negative control; PC, positive control.

CHO-XRS5 cells exposed to $\mathrm{Al}$ exhibited a significant increase in the number of MCNs only at the highest test concentration of the metal $(2.0 \mathrm{mg} / \mathrm{L})$ during the $72 \mathrm{~h}$ treatment (Figure 3A). There was a significant increase in the number of cells with $\mathrm{MCNs}$ for $\mathrm{CHO}$ cells treated with Mn only at $3.0 \mathrm{mg} / \mathrm{L}$ after $24 \mathrm{~h}$, whereas an increase was observed at concentrations $\geq 1.5 \mathrm{mg} / \mathrm{L}$ after $72 \mathrm{~h}$ of treatment (Figure 3B). In CHO-XRS5 cells, there was no significant difference in the number of MCNs during the $24 \mathrm{~h}$ treatment period; however, after $72 \mathrm{~h}$ of treatment, there were significant differences at concentrations $\geq 1.5 \mathrm{mg} / \mathrm{L}$ (Figure 3B).

\subsection{Comet Assay}

$\mathrm{Al}$ induced a significant increase $(p<0.05)$ in Tail DNA proportion in $\mathrm{CHO}$ cells with increasing concentration and exposure time (Figure 4A). Regarding Tail Length, there was a significant difference between the treatments and the NC at concentrations $\geq 0.6 \mathrm{mg} / \mathrm{L}$ during both periods of exposure (Figure 4B).

In CHO-XRS5 cells, there was a significant difference between the treated cells and the NC for Tail DNA percentage at $\mathrm{Al}$ concentrations $\geq 0.8 \mathrm{mg} / \mathrm{L}$ during both test periods (Figure $4 \mathrm{C}$ ) and for Tail Length at 0.4 and $0.8 \mathrm{mg} / \mathrm{L}$ for the 24 and $72 \mathrm{~h}$ treatments, respectively (Figure 4D). In $\mathrm{CHO}$ cells treated with $\mathrm{Mn}$, there was a significant increase in Tail $D N A$ percentage with increasing concentrations and exposure time (Figure 5A), while for 
Tail Length there was a significant difference at concentrations $\geq 0.3 \mathrm{mg} / \mathrm{L}$ during both assessment periods (Figure 5B).

A)

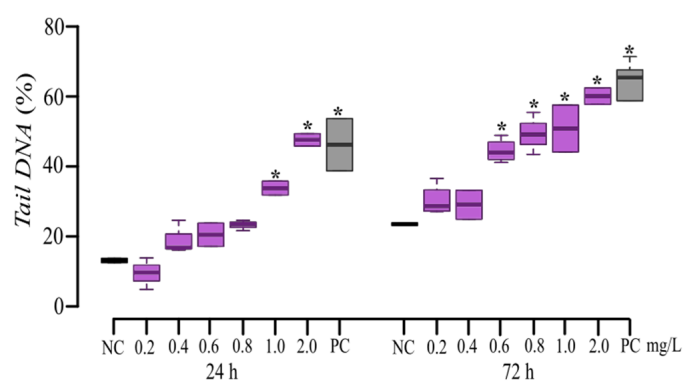

C)

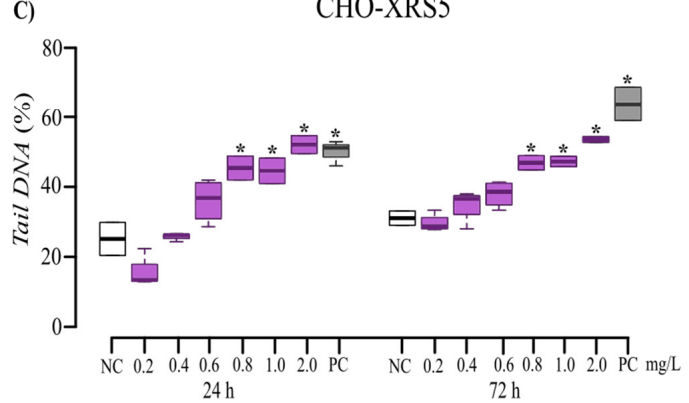

B)

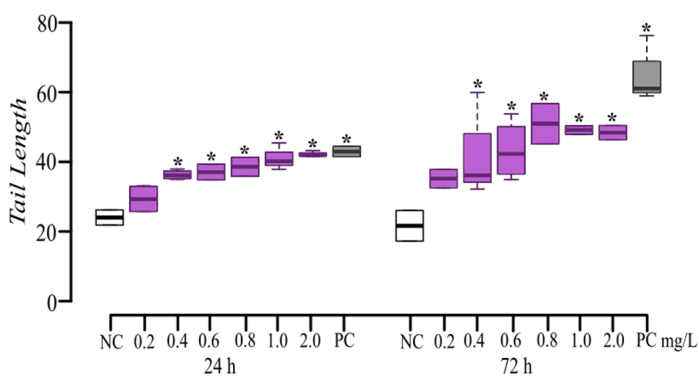

D)

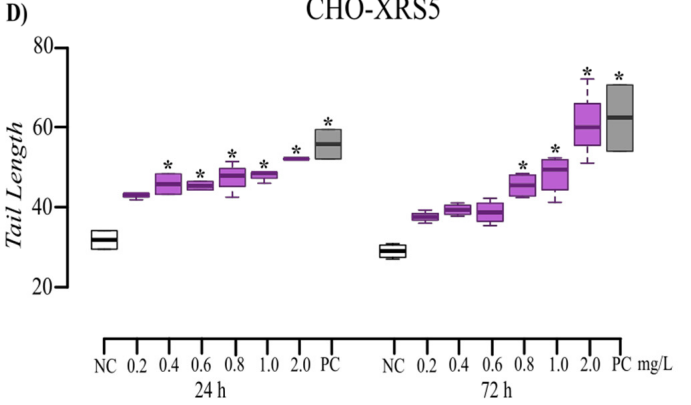

Figure 4. Tail DNA (A,C) and Tail Length (B,D) measured in CHO (A,B) and CHO-XRS5 (C,D) exposed to aluminum (violet) for 24 and $72 \mathrm{~h}$. The values are expressed as medians and interquartile deviations of two independent experiments. ${ }^{*} p<0.05$ compared to the NC by the Kruskal-Wallis test followed by Dunn's test. NC, negative control (white); PC, positive control (mitomycin C; gray).

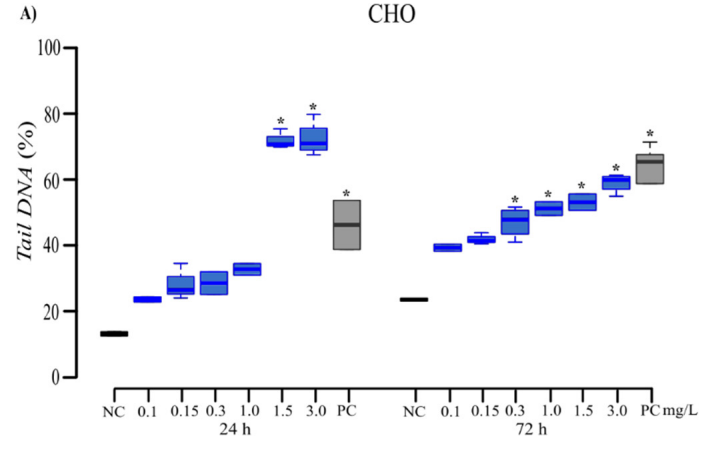

C)

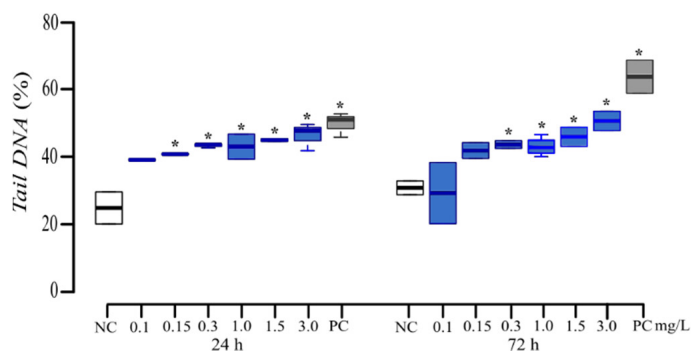

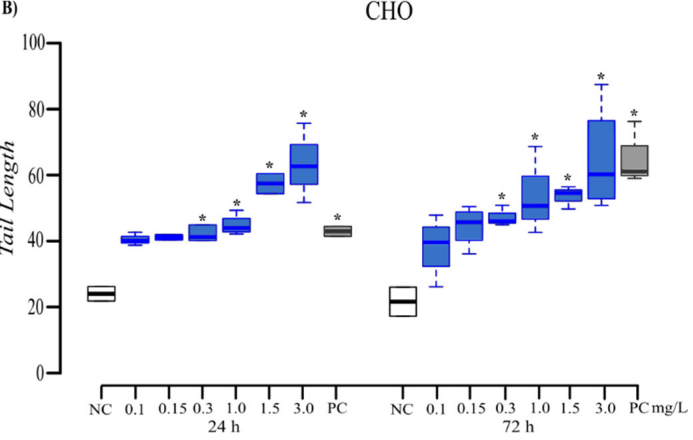

D)

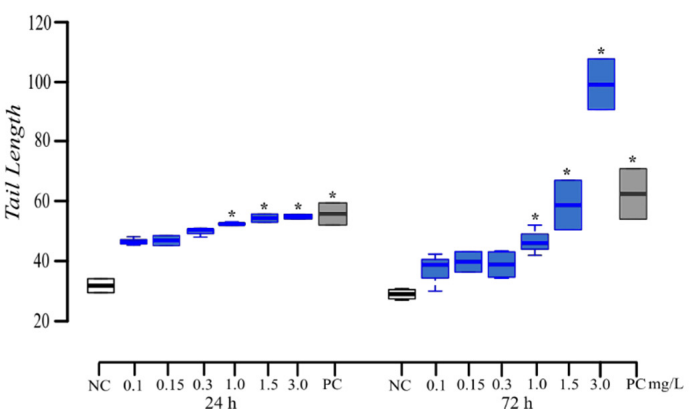

Figure 5. Tail DNA (A,C) and Tail Length $(\mathbf{B}, \mathbf{D})$ measured in CHO $(\mathbf{A}, \mathbf{B})$ and CHO-XRS5 $(\mathbf{C}, \mathbf{D})$ cells exposed to manganese (blue) for 24 and $72 \mathrm{~h}$. The values are expressed as medians and interquartile deviations of two independent experiments. ${ }^{*} p<0.05$ compared to the negative control by the Kruskal-Wallis test followed by Dunn's test. NC, negative control (white); PC, positive control (mitomycin C; gray). 
In the CHO-XRS5 cells, regarding the Tail DNA percentage, the negative effects of Mn were significant at concentrations $\geq 0.15 \mathrm{mg} / \mathrm{L}$ for the $24 \mathrm{~h}$ treatment and at concentrations $\geq 0.3 \mathrm{mg} / \mathrm{L}$ for the $72 \mathrm{~h}$ treatment (Figure $5 \mathrm{C}$ ). A difference in Tail Length was observed at concentrations $\geq 1.0 \mathrm{mg} / \mathrm{L}$ for both periods (Figure 5D).

\subsection{Salmonella Microsome Assay (Ames Test)}

In this study, we evaluated two bacterial strains (S. Typhimurium TA98 and TA100) with and without metabolic activation (S9) to test the mutagenicity of $\mathrm{Al}$ and $\mathrm{Mn}$. The strain TA98 was used for the detection of frameshift mutations, while the strain TA100 was used to detect base pair substitutions, primarily at guanine:cytosine (G:C) pairs.

As shown in Table 1, no mutagenic effect (MR > 2) was observed in strains TA98 and TA100 at any concentration of Al, either in the presence or absence of S9. We observed an $\mathrm{MR}<0.7$ in the range tested ( 0.2 to $1 \mathrm{mg} / \mathrm{L})$, demonstrating the cytotoxic effect of $\mathrm{Al}$ in the strains evaluated. Therefore, we reduced the concentration range of the evaluated metal to verify its mutagenic potential, and all concentrations tested $(0.025,0.05$, and $0.01 \mathrm{mg} / \mathrm{L})$ yielded negative results $(\mathrm{MR}<2)$ in both strains with and without metabolic activation (Table 1 and Table S1). However, the concentrations 0.025, 0.05, and $0.01 \mathrm{mg} / \mathrm{L}$ of $\mathrm{Al}$ in the presence and absence of S9 to the TA 100 strain compared to NC showed a tendency to become mutagenic, as they significantly increased the number of reversing colonies.

Table 1. Mutagenicity ratio (MR) of the $\mathrm{Al}$ expressed by the mean of reversals/plate \pm standard deviation to TA98 and TA100 strains of S. Typhimurium with (S+) and without (S-) metabolic activation.

\begin{tabular}{ccccc}
\hline \multirow{2}{*}{ Concentrations (mg/plate) } & \multicolumn{2}{c}{ TA 98 } & \multicolumn{2}{c}{ TA 100 } \\
\cline { 2 - 5 } & S+ (MR) & S- (MR) & S+ (MR) & $111.33 \pm 1.69$ \\
NC & $20.33 \pm 1.24$ & $23.33 \pm 1.24$ & $122.33 \pm 1.88$ & S- (MR) \\
0.025 & $19.66 \pm 0.44(0.96)$ & $28.66 \pm 3.55(1.22)$ & $149.70 \pm 8.44 *(1.22)$ & $149.33 \pm 1.11 *(1.34)$ \\
0.05 & $18.66 \pm 0.44(0.93)$ & $21.00 \pm 3.33(0.90)$ & $132.70 \pm 1.55 *(1.08)$ & $134.66 \pm 3.11 *(1.20)$ \\
0.1 & $24.00 \pm 1.30(1.2)$ & $27.00 \pm 2.00(1.15)$ & $163.00 \pm 4.00 *(1.33)$ & $136.50 \pm 4.50 *(1.22)$ \\
0.2 & $10.00 \pm 0.81(0.37)$ & $7.33 \pm 0.47(0.33)$ & $13.00 \pm 0.81(0.18)$ & $26.00 \pm 4.00(0.33)$ \\
0.4 & - & $10.33 \pm 0.47(0.46)$ & $18.00 \pm 1.41(0.25)$ & $26.50 \pm 1.50(0.34)$ \\
0.6 & - & $11.00 \pm 1.41(0.50)$ & $17.00 \pm 1.63(0.23)$ & $15.66 \pm 0.94(0.20)$ \\
0.8 & - & $9.33 \pm 0.47(0.42)$ & $16.33 \pm 1.24(0.23)$ & $17.33 \pm 1.24(0.22)$ \\
1.0 & - & $7.66 \pm 0.94(0.34)$ & $17.00 \pm 1.41(0.23)$ & $19.00 \pm 1.63(0.24)$ \\
PC & $321.00 \pm 11.00 *$ & $1315.00 \pm 8.00 *$ & $1338.00 \pm 11.00 *$ & $1428.00 \pm 6.00 *$ \\
\hline
\end{tabular}

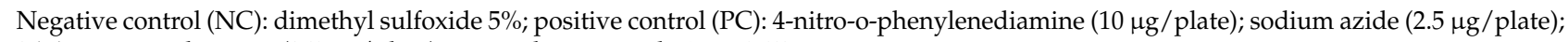
2AA-aminoanthracene ( $2.5 \mu \mathrm{g} /$ plate); -, no colony growth; * $p<0.05$.

At the higher metal concentrations, fewer bacterial colonies grew on the Petri dish. As observed by the Ames test, $\mathrm{Al}$ also showed a cytotoxic effect in the assay with cell lines $\mathrm{CHO}$ and CHO-XRS5, from the concentrations 0.6 and $0.2 \mathrm{mg} / \mathrm{L}$, respectively (Figure 1). According to the results for $\mathrm{Mn}$, no test concentration caused a positive mutagenic response when compared with the control in the two S. Typhimurium strains, with or without metabolic activation (Table 2). A cytotoxic effect was found at concentrations from 0.1 to $1.5 \mathrm{mg} / \mathrm{L}$; however, when the concentration range was reduced $(0.0125,0.025$, and $0.05 \mathrm{mg} / \mathrm{L})$, we observed negative results $(\mathrm{MR}<2)$ in both strains with and without metabolic activation (Table 2 and Table S1). The $0.0125 \mathrm{mg} / \mathrm{L}$ concentration with or without metabolic activation for the TA98 strain also significantly increased the number of reversing colonies in relation to the $\mathrm{NC}$, demonstrating the tendency to become mutagenic. A similar result was observed for the strain TA 100 at the concentration of $0.05 \mathrm{mg} / \mathrm{L}$ in the assay with metabolic activation.

In general, Mn demonstrated a cytotoxic effect as the concentration increased (Table 2) and when compared to that in the cellular assay, Mn demonstrated cytotoxicity in $\mathrm{CHO}$ cells from a concentration of $0.15 \mathrm{mg} / \mathrm{L}$ for $72 \mathrm{~h}$ of treatment and in CHO-XRS5 cells from $0.1 \mathrm{mg} / \mathrm{L}$ for $24 \mathrm{~h}$ of treatment (Figure 1). 
Table 2. Mutagenicity ratio (MR) of the manganese expressed by the mean of reversals/plate \pm standard deviation to TA98 and TA100 strains of S. Typhimurium with (S+) and without (S-) metabolic activation.

\begin{tabular}{ccccc}
\hline \multirow{2}{*}{ Concentrations (mg/plate) } & \multicolumn{2}{c}{ TA 98 } & \multicolumn{2}{c}{ TA 100 } \\
\cline { 2 - 5 } & S+ (MR) & S- (MR) & S+ (MR) & S- (MR) \\
\hline NC & $20.33 \pm 1.24$ & $23.33 \pm 1.24$ & $122.33 \pm 1.88$ & $111.33 \pm 1.69$ \\
0.0125 & $25.66 \pm 0.88^{*}(1.26)$ & $29.66 \pm 0.88 *(1.27)$ & $90.00 \pm 6.66(0.73)$ & $87.66 \pm 1.88(0.78)$ \\
0.025 & $20.33 \pm 0.44(1.00)$ & $22.66 \pm 1.11(0.97)$ & $108.66 \pm 2.22(0.88)$ & $92.33 \pm 2.22(0.82)$ \\
0.05 & $25.00 \pm 1.33(1.22)$ & $26.66 \pm 3.11(1.14)$ & $148.00 \pm 5.33 *(1.20)$ & $108.33 \pm 2.22(0.97)$ \\
0.1 & $10.66 \pm 1.24(0.39)$ & $8.33 \pm 0.94(0.37)$ & $18.00 \pm 5.00(0.25)$ & $12.66 \pm 0.47(0.16)$ \\
0.3 & $14.00 \pm 2.16(0.51)$ & $9.33 \pm 0.47(0.42)$ & - & - \\
1.0 & $8.66 \pm 1.88(0.32)$ & $6.50 \pm 0.50(0.29)$ & - & - \\
1.5 & $3.33 \pm 0.94(0.12)$ & $7.00 \pm 0.81(0.31)$ & - & - \\
PC & $321.00 \pm 11.00 *$ & $1315.00 \pm 8.00 *$ & $1338.00 \pm 11.00 *$ & $1428.00 \pm 6.00 *$ \\
\hline
\end{tabular}

Negative control (NC): dimethyl sulfoxide $5 \%$; positive control (PC): 4-nitro-o-phenylenediamine (10 $\mu \mathrm{g} / \mathrm{plate})$; sodium azide (2.5 $\mu \mathrm{g} / \mathrm{plate})$; 2AA-aminoanthracene $(2.5 \mu \mathrm{g} /$ plate $) ;-$, no colony growth; ${ }^{*} p<0.05$.

\section{Discussion}

Metals are non-biodegradable chemical contaminants that accumulate in living organisms that can be toxic to plants and microorganisms as well as affect human health [37]. Therefore, studies that evaluate their cytotoxicity, genotoxicity, and mutagenicity in organisms are extremely important. Thus, bioassays with plants [38-40], animals [16,41,42], and human cells $[5,16,43-45]$ are important tools for the assessment of the responses of organisms when exposed to metals.

Both in vitro and in vivo studies have demonstrated that exposure of cells to $\mathrm{Al}$ leads to reactive oxygen species (ROS) formation, lipid peroxidation, and oxidative damage of mitochondrial proteins, which results in cytotoxicity [46-48]. Concentration-dependent cytotoxicity of $\mathrm{Al}$ at concentrations similar to those used in this study $(0.2-1.0 \mathrm{mg} / \mathrm{L})$ has previously been observed in the lymphocytes and thymocytes of rats, with a significant reduction in cell viability directly proportional to the increase in $\mathrm{Al}$ concentration [49].

The reduction in cell viability observed in cells exposed to Mn after $24 \mathrm{~h}$ has also been found in studies conducted using other cell lines, where higher cytotoxicity is observed after a $24 \mathrm{~h}$ treatment period $[17,50,51]$. The mechanisms associated with the loss of cell viability due to Mn exposure still need to be clarified; however, oxidative stress due to the generation of ROS upon induction by Mn is related to cell death in several cell lines [52-56]. To elucidate the cytotoxic and genotoxic effects of $\mathrm{Al}$ and $\mathrm{Mn}$, a comparison was made between the wild type strain $\mathrm{CHO}$ and $\mathrm{CHO}-\mathrm{XRS5}$, a cell line lacking the ability to repair double-strand breaks efficiently. The reduction in cell viability upon exposure to the lowest concentration ( 0.2 and $0.1 \mathrm{mg} / \mathrm{L})$ of $\mathrm{Al}$ and Mn was observed only in CHO-XRS5 cells after a $24 \mathrm{~h}$ treatment period and may be due to the inefficiency of these cells to repair double-strand DNA breaks [24,25].

In this study, the parameters of nuclear buds, nucleoplasmic bridges, and MCN were analyzed to assess the genotoxic damage that $\mathrm{Al}$ and $\mathrm{Mn}$ can cause in cells. In general, $\mathrm{Al}$ and $\mathrm{Mn}$ caused significant genotoxic damage at the highest concentrations tested (above $1.0 \mathrm{mg} / \mathrm{L}$ ) with the exception of the formation of nuclear buds, in which case a significant increase was observed in CHO-XRS5 cells after $72 \mathrm{~h}$ of treatment with the lowest $\mathrm{Al}$ concentration tested $(0.2 \mathrm{mg} / \mathrm{L})$. Neither $\mathrm{Al}$ nor Mn caused a significant increase in the number of nucleoplasmic bridges in either of the cell lines tested; however, a study conducted by Porte Alcon et al. [52] reported an increase in the number of cells with nucleoplasmic bridges and micronuclei when murine microglial cells (BV 2) were exposed to high $\mathrm{Mn}$ concentrations (13.75 and $41.25 \mathrm{mg} / \mathrm{L}$ ).

$\mathrm{Al}$ induces DNA damage and may lead to cytotoxic, genotoxic, or carcinogenic alterations in cells [57]. The genotoxic effect of $\mathrm{AlCl}_{3}$ has been reported in human lymphocytes at concentrations $>0.135 \mathrm{mg} / \mathrm{L}$ after $72 \mathrm{~h}$ of exposure, with higher numbers of MCNs being observed at concentrations of 0.27 and $0.54 \mathrm{mg} / \mathrm{L}$ [16]. In relation to Mn, a significant 
difference in the number of MCNs between treatments and the NC was also observed in murine microglial cells (BV-2) [52] at concentrations of 13.75 and $41.25 \mathrm{mg} / \mathrm{L} \mathrm{Mn}$, which are higher than the concentrations used in this study. The significant increase in the number of MCNs in the CHO and CHO-XRS5 cell lines occurred at the highest Mn concentrations. An increase in DNA damage, as evidenced by the presence of nuclear buds and MCNs, may be a consequence of oxidative stress and/or increased nuclear expression of $\mathrm{cH} 2 \mathrm{AX}$ caused by exposure to $\mathrm{Mn}$ [52].

The comet assay showed that Al induced a significant increase in DNA damage to cells with increasing concentration and exposure time (Figure 4). Celik et al. [57] demonstrated a positive correlation between increased oxidative stress and DNA damage (as measured by the comet assay) in cells treated with Al. However, studies using more specific molecular techniques that assess epigenetic effects would be relevant for elucidating the mechanisms responsible for DNA damage due to $\mathrm{Al}$ exposure in $\mathrm{CHO}$ and $\mathrm{CHO}-\mathrm{XRS} 5$ cells.

Treatment with Mn induced a significant increase in DNA damage to cells with increasing concentrations for both cell lines, as evidenced by different DNA damage parameters. DNA damage was also detected in human lymphocytes exposed to Mn in different phases of the mitotic cycle [58] and in human neuroblastoma cells (SH-SY5Y) exposed to $\mathrm{Mn}$ for $24 \mathrm{~h}$ [17]. In the present study, when comparing the genotoxic damage between the $\mathrm{CHO}$ and $\mathrm{CHO}-\mathrm{XRS} 5$ cell lines, no greater amount of genotoxic damage was observed in the CHO-XRS5 cell line compared to that in the CHO cell line, which was not expected due to the inefficiency of these cell types in repairing double-stranded DNA breaks.

No mutagenic effect $(\mathrm{MR}>2)$ was observed in strains TA98 and TA100 treated with $\mathrm{Al}$ and $\mathrm{Mn}$ at any test concentration. The range tested $(0.2-2.0$ and $0.1-1.5 \mathrm{mg} / \mathrm{L}) \mathrm{had}$ an $\mathrm{MR}<0.7$, demonstrating the cytotoxic effect of the compound in the strains evaluated. Our results are consistent with those of previously published studies for both strains regarding treatment with Al. Saraç et al. [59] showed no mutagenic effects in the Ames test for the concentrations of $\mathrm{AlCl}_{3}$ evaluated $(0.025,0.25$, and $1.25 \mathrm{mg} / \mathrm{mL}$ plate). In another study, Ahn and Jeffery [13] verified that Al did not cause mutagenic effects at concentrations of 0.3 and $3.0 \mathrm{mg} / \mathrm{L}$ but was suggested as toxic to the TA98 strain. This toxicity observed by Ahn and Jeffery [13] should be explained because when the viability of cells was evaluated, $\mathrm{Al}$ caused a decrease in viability compared to that in the NC. Based on the results of our study, we could infer that the cytotoxic effects on the strains evaluated interfered in the detection of mutagenic effects since $\mathrm{Al}$ and Mn could have caused DNA damage that the strains were unable to repair, which caused them to stop growing, thereby preventing the detection of mutagenic effects.

\section{Conclusions}

$\mathrm{Al}$ and $\mathrm{Mn}$ at concentrations detected previously in groundwater (the maximum limit permitted by law as well as higher values) and evaluated in this study were shown to have cytotoxic and genotoxic effects in hamster ovary cell lines. This study identified the cytotoxic effects of Al and Mn, as evidenced in the Salmonella microsome assay, even at concentrations that were within the legally permissible limits. These results may help hasten the review of established regulatory standards of groundwater for human consumption.

Supplementary Materials: The following are available online at https:/ / www.mdpi.com/article/10 $.3390 /$ toxics $9070153 /$ s1, Table S1: Mutagenicity (MR) results obtained in the Salmonella/microsome assay from the concentrations of $\mathrm{Al}$ and Mn using the S. Typhimurium strains TA98 and TA100 in the presence and absence of metabolic activation system (S9).

Author Contributions: L.F.V.F., B.d.A.C., A.B., E.L.d.S. and K.M.P.d.O. conceived the study; L.F.V.F., D.d.S.B., S.M.F.F.K. and P.F.d.C. conducted the experiments; L.F.V.F., L.F.V., B.d.A.C., D.d.S.B., P.F.d.C., E.L.d.S. and K.M.P.d.O. analyzed the data; and L.F.V.F. wrote the manuscript. All authors have read and agreed to the published version of the manuscript. 
Funding: This work was supported by the National Health Foundation of Brazil (FUNASA), the National Council for the Improvement of Higher Education (CAPES), the Development of Education, Science and Technology of the State of Mato Grosso do Sul (FUNDECT), as well as the Federal University of Grande Dourados (UFGD) who provided logistical support.

Institutional Review Board Statement: Not applicable.

Informed Consent Statement: Not applicable.

Data Availability Statement: All the data in the current study could be available by contacting the corresponding author.

Acknowledgments: We thank Elza Tiemi Sakamoto Hojo of the Biology Department of the Faculty of Philosophy, Sciences and Letters of Ribeirão Preto/SP Brazil for graciously providing us with the hamster ovary cell lines, CHO and CHO-XRS5.

Conflicts of Interest: The authors declare that they have no known competing financial interests or personal relationships that could have appeared to influence the work reported in this paper.

\section{References}

1. Dhanakumar, S.; Solaraj, G.; Mohanraj, R. Heavy Metal Partitioning in Sediments and Bioaccumulation in Commercial Fish Species of Three Major Reservoirs of River Cauvery Delta Region, India. Ecotoxicol. Environ. Saf. 2015, 113, 145-151. [CrossRef]

2. Jayaprakash, M.; Kumar, R.S.; Giridharan, L.; Sujitha, S.B.; Sarkar, S.K.; Jonathan, M.P. Bioaccumulation of Metals in Fish Species from Water and Sediments in Macrotidal Ennore Creek, Chennai, SE Coast of India: A Metropolitan City Effect. Ecotoxicol. Environ. Saf. 2015, 120, 243-255. [CrossRef]

3. Izah, S.C.; Chakrabarty, N.; Srivastav, A.L. A Review on Heavy Metal Concentration in Potable Water Sources in Nigeria: Human Health Effects and Mitigating Measures. Expo. Health 2016, 8, 285-304. [CrossRef]

4. Van Wendel de Joode, B.; Barbeau, B.; Bouchard, M.F.; Mora, A.M.; Skytt, Å.; Córdoba, L.; Quesada, R.; Lundh, T.; Lindh, C.H.; Mergler, D. Manganese Concentrations in Drinking Water from Villages near Banana Plantations with Aerial Mancozeb Spraying in Costa Rica: Results from the Infants' Environmental Health Study (ISA). Environ. Poll. 2016, 215, 247-257. [CrossRef]

5. Lima, P.D.L.; Vasconcellos, M.C.; Montenegro, R.C.; Bahia, M.O.; Costa, E.T.; Antunes, L.M.G.; Burbano, R.R. Genotoxic Effects of Aluminum, Iron and Manganese in Human Cells and Experimental Systems: A Review of the Literature. Hum. Exp. Toxicol. 2011, 30, 1435-1444. [CrossRef]

6. Krewski, D.; Yokel, R.A.; Nieboer, E.; Borchelt, D.; Cohen, J.; Harry, J.; Kacew, S.; Lindsay, J.; Mahfouz, A.M.; Rondeau, V. Human Health Risk Assessment for Aluminium, Aluminium Oxide, and Aluminium Hydroxide. J. Toxicol. Environ. Health B Crit. Rev. 2007, 10 (Suppl. S1), 1-269. [CrossRef]

7. Willhite, C.C.; Karyakina, N.A.; Yokel, R.A.; Yenugadhati, N.; Wisniewski, T.M.; Arnold, I.M.F.; Momoli, F.; Krewski, D. Systematic Review of Potential Health Risks Posed by Pharmaceutical, Occupational and Consumer Exposures to Metallic and Nanoscale Aluminum, Aluminum Oxides, Aluminum Hydroxide and Its Soluble Salts. Crit. Rev. Toxicol. 2014, 44 (Suppl. S4), 1-80. [CrossRef]

8. Ahamad, A.; Raju, N.J.; Madhav, S.; Gossel, W.; Wycisk, P. Impact of Non-Engineered Bhalswa Landfill on Groundwater from Quaternary Alluvium in Yamuna Flood Plain and Potential Human Health Risk, New Delhi, India. Quat. Int. 2019, 507, 352-369. [CrossRef]

9. Alexandrov, P.N.; Pogue, A.I.; Lukiw, W.J. Synergism in Aluminum and Mercury Neurotoxicity. Integr. Food Nutr. Metab. 2018, 5. [CrossRef]

10. Verstraeten, S.V.; Aimo, L.; Oteiza, P.I. Aluminium and Lead: Molecular Mechanisms of Brain Toxicity. Arch. Toxicol. 2008, 82, 789-802. [CrossRef]

11. Bornhorst, J.; Ebert, F.; Hartwig, A.; Michalke, B.; Schwerdtle, T. Manganese Inhibits Poly (ADP-Ribosyl) Ation in Human Cells: A Possible Mechanism behind Manganese-Induced Toxicity? J. Environ. Monit. 2010, 12, 2062-2069. [CrossRef]

12. Horning, K.J.; Caito, S.W.; Tipps, K.G.; Bowman, A.B.; Aschner, M. Manganese Is Essential for Neuronal Health. Annu. Rev. Nutr. 2015, 35, 71-108. [CrossRef] [PubMed]

13. Ahn, H.W.; Jeffery, E.H. Effect of Aluminum on Fluoride Uptake by Salmonella Typhimurium TA98; Implications for the Ames Mutagenicity Assay. J. Toxicol. Environ. Health 1994, 41, 357-368. [CrossRef] [PubMed]

14. Alimba, C.G.; Dhillon, V.; Bakare, A.A.; Fenech, M. Genotoxicity and Cytotoxicity of Chromium, Copper, Manganese and Lead, and Their Mixture in WIL2-NS Human B Lymphoblastoid Cells Is Enhanced by Folate Depletion. Mutat. Res. Genet. Toxicol. Environ. Mutagen. 2016, 798-799, 35-47. [CrossRef] [PubMed]

15. Geyikoglu, F.; Türkez, H.; Bakir, T.O.; Cicek, M. The Genotoxic, Hepatotoxic, Nephrotoxic, Haematotoxic and Histopathological Effects in Rats after Aluminium Chronic Intoxication. Toxicol. Ind. Health 2013, 29, 780-791. [CrossRef]

16. Paz, L.N.F.; Moura, L.M.; Feio, D.C.A.; Cardoso, M.d.S.G.; Ximenes, W.L.O.; Montenegro, R.C.; Alves, A.P.N.; Burbano, R.R.; Lima, P.D.L. Evaluation of in Vivo and in Vitro Toxicological and Genotoxic Potential of Aluminum Chloride. Chemosphere 2017, 175, 130-137. [CrossRef] 
17. Stephenson, A.P.; Schneider, J.A.; Nelson, B.C.; Atha, D.H.; Jain, A.; Soliman, K.F.A.; Aschner, M.; Mazzio, E.; Renee Reams, R. Manganese-Induced Oxidative DNA Damage in Neuronal SH-SY5Y Cells: Attenuation of Thymine Base Lesions by Glutathione and N-Acetylcysteine. Toxicol. Lett. 2013, 218, 299-307. [CrossRef]

18. Gonçalves, P.P.; Silva, V.S. Does Neurotransmission Impairment Accompany Aluminium Neurotoxicity? J. Inorg. Biochem. 2007, 101, 1291-1338. [CrossRef]

19. Peres, T.V.; Schettinger, M.R.C.; Chen, P.; Carvalho, F.; Avila, D.S.; Bowman, A.B.; Aschner, M. Manganese-Induced Neurotoxicity: A Review of Its Behavioral Consequences and Neuroprotective Strategies. BMC Pharmacol. Toxicol. 2016, 17, 57. [CrossRef]

20. Wang, Z.; Wei, X.; Yang, J.; Suo, J.; Chen, J.; Liu, X.; Zhao, X. Chronic Exposure to Aluminum and Risk of Alzheimer's Disease: A Meta-Analysis. Neurosci. Lett. 2016, 610, 200-206. [CrossRef]

21. Preston, R.J.; Au, W.; Bender, M.A.; Brewen, J.G.; Carrano, A.V.; Heddle, J.A.; McFee, A.F.; Wolff, S.; Wassom, J.S. Mammalian In Vivo and In Vitro Cytogenetic Assays: A Report of the U.S. EPA's Gene-Tox Program. Mutat. Res. 1981, 87, 143-188. [CrossRef]

22. Erexson, G.L.; Periago, M.V.; Spicer, C.S. Differential Sensitivity of Chinese Hamster V79 and Chinese Hamster Ovary (CHO) Cells in the in Vitro Micronucleus Screening Assay. Mutat. Res. 2001, 495, 75-80. [CrossRef]

23. OECD. Test No. 487, In Vitro Mammalian Cell Micronucleus Test, OECD Guidelines for the Testing of Chemicals, Section 4; OECD Publishing: Paris, France, 2016. [CrossRef]

24. Costa, N.D.; Bryant, P.E. Repair of DNA Single-Strand and Double-Strand Breaks in the Chinese Hamster Xrs 5 Mutant Cell Line as Determined by DNA Unwinding. Mutat. Res. 1988, 194, 93-99. [CrossRef]

25. Darroudi, F.; Natarajan, A.T. Cytological Characterization of Chinese Hamster Ovary X-ray-Sensitive Mutant Cells Xrs 5 and Xrs 6. I. Induction of Chromosomal Aberrations by X-Irradiation and its Modulation with 3-Aminobenzamide and Caffeine. Mutat. Res. 1987, 177, 133-148. [CrossRef]

26. Kemp, L.M.; Jeggo, P.A. Radiation-Induced Chromosome Damage in X-Ray-Sensitive Mutants (Xrs) of the Chinese Hamster Ovary Cell Line. Mutat. Res. 1986, 166, 255-263. [CrossRef]

27. Souza, T.A.J.; Franchi, L.P.; Rosa, L.R.; da Veiga, M.A.M.S.; Takahashi, C.S. Cytotoxicity and Genotoxicity of Silver Nanoparticles of Different Sizes in CHO-K1 and CHO-XRS5 Cell Lines. Mutat. Res. Genet. Toxicol. Environ. Mutagen 2016, 795, 70-83. [CrossRef]

28. Francisco, L.F.V.; do Amaral Crispim, B.; Spósito, J.C.V.; Solórzano, J.C.J.; Maran, N.H.; Kummrow, F.; do Nascimento, V.A.; Montagner, C.C.; De Oliveira, K.M.P.; Barufatti, A. Metals and Emerging Contaminants in Groundwater and Human Health Risk Assessment. Environ. Sci. Pollut. Res. Int. 2019, 26, 24581-24594. [CrossRef] [PubMed]

29. Brazil National Environment Council (CONAMA). Resolution no 396 of 3 April 2008. 2008. Available online: http:/ / www2.mma. gov.br/port/conama/legiabre.cfm?codlegi=562 (accessed on 20 October 2019).

30. Oliveira, R.J.; Ribeiro, L.R.; da Silva, A.F.; Matuo, R.; Mantovani, M.S. Evaluation of Antimutagenic Activity and Mechanisms of Action of Beta-Glucan from Barley, in CHO-K1 and HTC Cell Lines Using the Micronucleus Test. Toxicol. In Vitro 2006, 20, 1225-1233. [CrossRef] [PubMed]

31. Fenech, M. Cytokinesis-Block Micronucleus Cytome Assay. Nat. Protoc. 2007, 2, 1084-1104. [CrossRef] [PubMed]

32. Singh, N.P.; McCoy, M.T.; Tice, R.R.; Schneider, E.L. A Simple Technique for Quantitation of Low Levels of DNA Damage in Individual Cells. Exp. Cell Res. 1988, 175, 184-191. [CrossRef]

33. Mortelmans, K.; Zeiger, E. The Ames Salmonella/Microsome Mutagenicity Assay. Mutat. Res. 2000, 455, 29-60. [CrossRef]

34. OECD. Test. 471: Bacterial Reverse Mutation Test; Organization for Economic Cooperation and Development (OECD): Paris, France, 1997.

35. R Core Team. R: A Language and Environment for Statistical Computing; R Foundation for Statistical Computing: Vienna, Austria, 2018.

36. Bernstein, L.; Kaldor, J.; McCann, J.; Pike, M.C. An Empirical Approach to the Statistical Analysis of Mutagenesis Data from the Salmonella Test. Mutat. Res. 1982, 97, 267-281. [CrossRef]

37. Tang, J.; Zhang, J.; Ren, L.; Zhou, Y.; Gao, J.; Luo, L.; Yang, Y.; Peng, Q.; Huang, H.; Chen, A. Diagnosis of Soil Contamination Using Microbiological Indices: A Review on Heavy Metal Pollution. J. Environ. Manag. 2019, 242, 121-130. [CrossRef] [PubMed]

38. Petrescu, I.; Sarac, I.; Bonciu, E.; Madosa, E.; Rosculete, C.A.; Butnariu, M. Study Regarding the Cytotoxic Potential of Cadmium and Zinc in Meristematic Tissues of Basil (Ocimum Basilicum L.). Caryologia 2020, 73. [CrossRef]

39. Bonciu, E.; Firbas, P.; Fontanetti, C.S.; Wusheng, J.; Karaismailoğlu, M.C.; Liu, D.; Menicucci, F.; Pesnya, D.S.; Popescu, A.; Romanovsky, A.V.; et al. An Evaluation for the Standardization of the Allium Cepa Test as Cytotoxicity and Genotoxicity Assay. Caryologia 2018, 71, 191-209. [CrossRef]

40. Francisco, L.F.V.; Crispim, B.D.A.; Viana, L.F.; Nascimento, H.D.S.; Raposo Junior, J.L.; Grisolia, A.B. Cytotoxicity, Genotoxicity and Mutagenicity of Aluminum, Manganese and Lead in Meristematic Cells of Root Allium Cepa. Orbital Electron. J. Chem. 2018, 10, 60-65. [CrossRef]

41. Taylor, C.A.; Tuschl, K.; Nicolai, M.M.; Bornhorst, J.; Gubert, P.; Varão, A.M.; Aschner, M.; Smith, D.R.; Mukhopadhyay, S. Maintaining Translational Relevance in Animal Models of Manganese Neurotoxicity. J. Nutr. 2020, 150, 1360-1369. [CrossRef]

42. Zhao, L.; Xia, Z.; Wang, F. Zebrafish in the Sea of Mineral (Iron, Zinc, and Copper) Metabolism. Front. Pharmacol. $2014,5$. [CrossRef]

43. Benitez-Trinidad, A.B.; Herrera-Moreno, J.F.; Vázquez-Estrada, G.; Verdín-Betancourt, F.A.; Sordo, M.; Ostrosky-Wegman, P.; Bernal-Hernández, Y.Y.; Medina-Díaz, I.M.; Barrón-Vivanco, B.S.; Robledo-Marenco, M.L.; et al. Cytostatic and Genotoxic Effect of Temephos in Human Lymphocytes and HepG2 Cells. Toxicol. In Vitro 2015, 29, 779-786. [CrossRef] 
44. Demir, E.; Burgucu, D.; Turna, F.; Aksakal, S.; Kaya, B. Determination of $\mathrm{TiO}_{2}, \mathrm{ZrO}_{2}$, and $\mathrm{Al}_{2} \mathrm{O}_{3}$ Nanoparticles on Genotoxic Responses in Human Peripheral Blood Lymphocytes and Cultured Embyronic Kidney Cells. J. Toxicol. Environ. Health A 2013, 76, 990-1002. [CrossRef]

45. Gajski, G.; Ladeira, C.; Gerić, M.; Garaj-Vrhovac, V.; Viegas, S. Genotoxicity Assessment of a Selected Cytostatic Drug Mixture in Human Lymphocytes: A Study Based on Concentrations Relevant for Occupational Exposure. Environ. Res. 2018, 161, 26-34. [CrossRef] [PubMed]

46. Kumar, V.; Bal, A.; Gill, K.D. Impairment of Mitochondrial Energy Metabolism in Different Regions of Rat Brain Following Chronic Exposure to Aluminium. Brain Res. 2008, 1232, 94-103. [CrossRef] [PubMed]

47. Liaquat, L.; Sadir, S.; Batool, Z.; Tabassum, S.; Shahzad, S.; Afzal, A.; Haider, S. Acute Aluminum Chloride Toxicity Revisited: Study on DNA Damage and Histopathological, Biochemical and Neurochemical Alterations in Rat Brain. Life Sci. 2019, 217, 202-211. [CrossRef]

48. Xu, F.; Liu, Y.; Zhao, H.; Yu, K.; Song, M.; Zhu, Y.; Li, Y. Aluminum Chloride Caused Liver Dysfunction and Mitochondrial Energy Metabolism Disorder in Rat. J. Inorg. Biochem. 2017, 174, 55-62. [CrossRef] [PubMed]

49. Kamalov, J.; Carpenter, D.O.; Birman, I. Cytotoxicity of Environmentally Relevant Concentrations of Aluminum in Murine Thymocytes and Lymphocytes. J. Toxicol. 2011, 2011. [CrossRef]

50. Zhang, L.; Sang, H.; Liu, Y.; Li, J. Manganese Activates Caspase-9-Dependent Apoptosis in Human Bronchial Epithelial Cells. Hum. Exp. Toxicol. 2013, 32, 1155-1163. [CrossRef]

51. Zhao, F.; Zhang, J.-B.; Cai, T.-J.; Liu, X.-Q.; Liu, M.-C.; Ke, T.; Chen, J.-Y.; Luo, W.-J. Manganese Induces P21 Expression in PC12 Cells at the Transcriptional Level. Neuroscience 2012, 215, 184-195. [CrossRef]

52. Porte Alcon, S.; Gorojod, R.M.; Kotler, M.L. Regulated Necrosis Orchestrates Microglial Cell Death in Manganese-Induced Toxicity. Neuroscience 2018, 393, 206-225. [CrossRef] [PubMed]

53. Gonzalez, L.E.; Juknat, A.A.; Venosa, A.J.; Verrengia, N.; Kotler, M.L. Manganese Activates the Mitochondrial Apoptotic Pathway in Rat Astrocytes by Modulating the Expression of Proteins of the Bcl-2 Family. Neurochem. Int. 2008, 53, 408-415. [CrossRef]

54. Martinez-Finley, E.J.; Gavin, C.E.; Aschner, M.; Gunter, T.E. Manganese Neurotoxicity and the Role of Reactive Oxygen Species. Free Radic. Biol. Med. 2013, 62, 65-75. [CrossRef]

55. Prabhakaran, K.; Ghosh, D.; Chapman, G.D.; Gunasekar, P.G. Molecular Mechanism of Manganese Exposure-Induced Dopaminergic Toxicity. Brain Res. Bull. 2008, 76, 361-367. [CrossRef]

56. Tamm, C.; Sabri, F.; Ceccatelli, S. Mitochondrial-Mediated Apoptosis in Neural Stem Cells Exposed to Manganese. Toxicol. Sci. 2008, 101, 310-320. [CrossRef] [PubMed]

57. Celik, H.; Celik, N.; Kocyigit, A.; Dikilitas, M. The Relationship between Plasma Aluminum Content, Lymphocyte DNA Damage, and Oxidative Status in Persons Using Aluminum Containers and Utensils Daily. Clin. Biochem. 2012, 45, 1629-1633. [CrossRef] [PubMed]

58. Lima, P.D.L.; Vasconcellos, M.C.; Bahia, M.O.; Montenegro, R.C.; Pessoa, C.O.; Costa-Lotufo, L.V.; Moraes, M.O.; Burbano, R.R. Genotoxic and Cytotoxic Effects of Manganese Chloride in Cultured Human Lymphocytes Treated in Different Phases of Cell Cycle. Toxicol. In Vitro 2008, 22, 1032-1037. [CrossRef] [PubMed]

59. Sarac, N.; Ugur, A.; Karaca, I. Evaluation of Antioxidant and Antimutagenic Activities of Aluminum Chloride. Eur. Oral. Res. 2019, 53, 51-55. [CrossRef] [PubMed] 